\title{
The Removal of Organic Acids and Aldehydes from Gases Emitted from Composting Municipal Waste
}

\author{
Monika Wierzbińska' \\ 1 Department of Environmental Protection and Engineering, University of Bielsko-Biala, Poland \\ email: mwierzbinska@ath.bielsko.pl
}

\begin{abstract}
The article describes an experiment conducted under industrial (real) conditions in a municipal waste composting facility. The waste gases emitted from composting processes were passed through an experimental installation built in a semi-technical scale. The installation consisted of two biofilters which were filled with different aluminosilicate beds with average granulation of $4-10 \mathrm{~mm}$. The sorbents were inoculated with a mixture of microorganisms bred on the mineral bed, previously operating in the tank with the waste from that composting facility. Malodorous gases were passed through the installation and concentrations of organic acids and aldehydes before and after passing through biofilters with the examined sorbents. The aim of the experiment was to determine which of the two mineral sorbents better removes the analysed contaminations from post-production gases. The experiment lasted for a month, as difficult and highly variable industrial conditions caused problems with operation and the experiment was suddenly interrupted. The study will be continued after the introduction of design changes in the installation. After the month of conducting the study it can be conclude that in the first weeks of the study, before the dampness of sorbents took place, halloysite reduced the concentrations of acetic acid in $80-99 \%$, and of acetaldehyde in $96-98 \%$. The other aluminosilicate caused a drop in the concentrations by $97-98 \%$ and $92-86 \%$, respectively. Moreover, in the experiment planned in the semi-technical scale, it was not possible to determine the overall performances of mineral biofilters due to unstable operating conditions and ending the experiment prematurely. The halloysite sorbent finally turned out to be potentially the more efficient than the other aluminosilicate sorbent.
\end{abstract}

Keywords: halloysite, composting, deodorisation, aluminosilicates, mineral sorbents

\section{INTRODUCTION}

Deodorisation is one of more difficult issues of the waste gases treatment technique. A low odour detection threshold of numerous gases characterised by unpleasant smell is the reason for which in most cases it is necessary to remove practically all odour substance to eliminate it. There are a lot of deodorisation methods. One of them is adsorption [Kwaśny 2014]. If a sorbent is inoculated with a mixture of specially prepared micro-organisms, the deodorisation process can be conducted in biofilters.

Every method has its advantages and disadvantages, and their application depends not only on the composition of the contaminated air, the amount of the air which must be treated in the unit of time and the amount of contaminants contained in it, but also on the technical capabilities. In the majority of the methods, sealing the installation and supplying the contaminated air to the devices or the installation in which deodorisation is conducted, are necessary.

The unwanted odours occurring in the surroundings of the air contamination sources are the main reason for the complaints of population about the quality of the environment. In some situations they are associated with the occurrence of health risk, in others - with discomfort. The results of intervention controls carried out by inspectors usually confirm the legitimacy of the complaints - high level of nuisance of the assessed facilities [Kośmider 2002]. Unfortunately, the lack of legal regulations, standards and the 
odour assessment methodology of the air quality causes low effectiveness of administrative decisions ordering the reduction of odour emissions. However, the problems of odours should be treated seriously, particularly in the case of designing new installations. The legal acts within that scope are already possessed by: Great Britain, Germany, the Netherlands, the Czech Republic, Denmark, Australia, the US, Canada, Japan, South Korea and New Zealand [Kwarciak-Kozłowska, 2014].

\section{Odour substances in individual stages of composting}

During the biological processing of waste, that is composting, malodorous substances, commonly called odours, are formed. They include, among others, short-chain fatty acids, amines, aliphatic and aromatic hydrocarbons, organic and non-organic sulphides, terpenes, ammonia and hydrogen sulphide, alcohols, aldehydes and ketones. The applied composting technology and the composition of the input mixture have a decisive impact not only on the compost quality but also on the qualitative and quantitative composition of the emitted gases [Kwarciak-Kozłowska 2014] [Wieczorek 1998]. The type of the emitted odorants also depends on the phase of the process (Table 1).

A lot of authors in their works report on almost 500 substances forming during the composting process, including about 100 odour-active substances [Jędrczak 2005]. The emission of odours during the oxygenic stabilisation of waste is also influenced by the way the process is conducted.

The formation of odour compounds occurs on all technological stages of waste neutralisation (Table 1) [Kwarciak-Kozłowska et al. 2014] [Sówka 2014]. Due to considerable nuisance of the gases emitted from composting processes and the low odour detection threshold, there is a justified necessity to eliminate the problem. One of the willingly applied methods of the post-process gases deodorisation is the gas biofiltration method. The methods are still studied by scientists in order to optimise processes, among others through the search of new sorbents. The article presents the research in the semi-technical scale in which mineral sorbents were used as the filling of biofilters. The process effectiveness was analysed based on the changes in the concentrations of aldehydes and organic acids. The halloysite from Dunino bed in Poland, as well as another aluminosilicate were used as sorbents.

Halloysite (HNT) is a mineral belonging to the group of kaolinite- serpentinite with crystal chemical formula $\mathrm{Al}_{4} \mathrm{SiO}_{4} \mathrm{O}_{10}(\mathrm{OH})_{8}$ [Guggenheim 2006] [Veerabadran 2007]. Halloysite is included in the group of layered minerals containing $\mathrm{SiO}_{2}$ (44\%), $\mathrm{Al}_{2} \mathrm{O}_{3}(38 \%), \mathrm{H}_{2} \mathrm{O}(15 \%)$ and trace amounts of metal oxides (e.g. iron oxide) [Szczygielska 2010] [Yuan 2008] and capable of forming lamellar, tubular or plank crystals [Du 2010] [Pasbakhsh 2012] [Matusik 2012]. In nature, it is found as a rock-forming mineral occurring as a result of hydrothermal changes or surface weathering of aluminosilicates, e.g. potassium feldspar [Machnicka 2016]. HNT is characterised by a relatively large specific surface area and porosity; it has good ion exchange properties, it can be easily modified chemically and mechanically. Therefore, it is applied in numerous areas of industry and environmental protection [Mingliang 2010] [Ravindra 2012] [Banaś 2013]. The average specific surface area of halloysite is $56.2-58.0 \mathrm{~m}^{2} / \mathrm{g}$ [Radziemska 2018]. According to some sources, the specific surface area of this mineral can reach up to $400 \mathrm{~m}^{2} / \mathrm{g}$ [Żarczyński 2014]. The photograph of this mineral is presented in Figure 1, and the structural schematic in Figure 2.

\section{Methodology}

The experiment was conducted under industrial (real) conditions at the premises of a municipal waste composting facility. The waste gases emitted from composting processes were passed through an experimental installation built in semi-technical scale. The installation consisted of two biofilters which were filled with different

Table 1. Odour substances (odorants) identified in individual stages of composting [Kwarciak-Kozłowska et al. 2014]

\begin{tabular}{|l|l|c|}
\hline \multicolumn{1}{|c|}{ Composting stage } & \multicolumn{1}{|c|}{ Characteristic odour substances } & Odour concentration [ou $/ \mathrm{m}^{3}$ ] \\
\hline Preliminary composting & $\begin{array}{l}\text { Aldehydes, alcohols, organic acid esters, ketones, sulfides, } \\
\text { turpentines }\end{array}$ & $6000-25000$ \\
\hline Thermophilic stage & Ketones, terpenes, ammonia, organosulphur compounds & $1000-9000$ \\
\hline Cooling & Sulphides, ammonia, terpenes & $150-3000$ \\
\hline
\end{tabular}




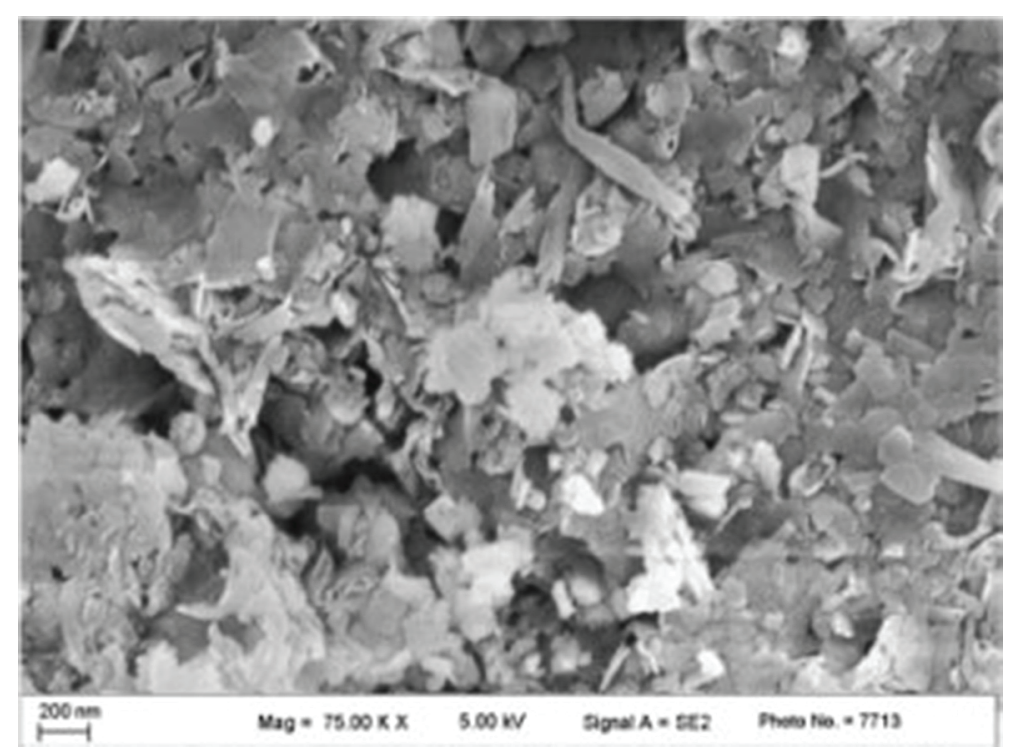

Figure 1. The structure of the halloysite from "Dunino" mine [Sakiewicz 2015]

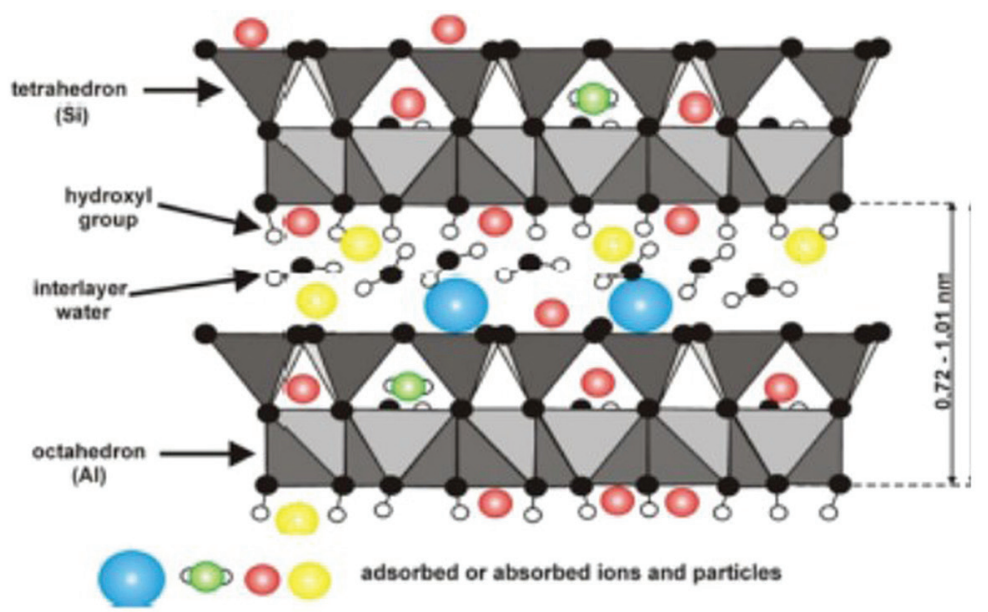

Figure 2. Structural schematic of HNT [Sakiewicz 2015]

beds of aluminosilicate with average granulation of $4-10 \mathrm{~mm}$. One of them was halloysite from the Dunino mine in Poland. The sorbents were inoculated with the mixture of micro-organisms bred on the mineral bed previously operating in the tank of waste from the composting facility. The examined mineral sorbents were marked as $\mathrm{H}$ for halloysite and AS for aluminosilicate (Figure 3). Malodorous gases were passed through the installation and the concentrations of organic acids and aldehydes were analysed before and after passing through the biofilters with the studied sorbents. The aim of the experiment was to determine which of the two mineral sorbents better removes the analysed contaminations from the post-process gases. The discussed experimental installation is presented in Figure 3.
The installation consisted of two biofilters of $1,500 \mathrm{~mm}$ in height and $27 \mathrm{~mm}$ in diameter, made of plastic resistant to the chemical and thermal factors, closed from the top with tight lids equipped with half-inch tubes and stubs for sample taking. At the height of $5 \mathrm{~cm}$ from the bottom of the biofilters there were stubs with which the leachate from the beds were drained off. Both biofilters were filled with the $\mathrm{H}$ and AS sorbents, respectively, suspended on steel meshes at the height of $20 \mathrm{~cm}$ from the bottom of the biofilters. The height of the beds was $115 \mathrm{~cm}$. Each biofilter had measuring stubs on the inlet and the outlet. The gases entering the biofilters were preliminarily treated from ammonia and moistened. The retention time of the gas in the bed was $50 \mathrm{sec}$. The gas meters installed upstream of the filters 


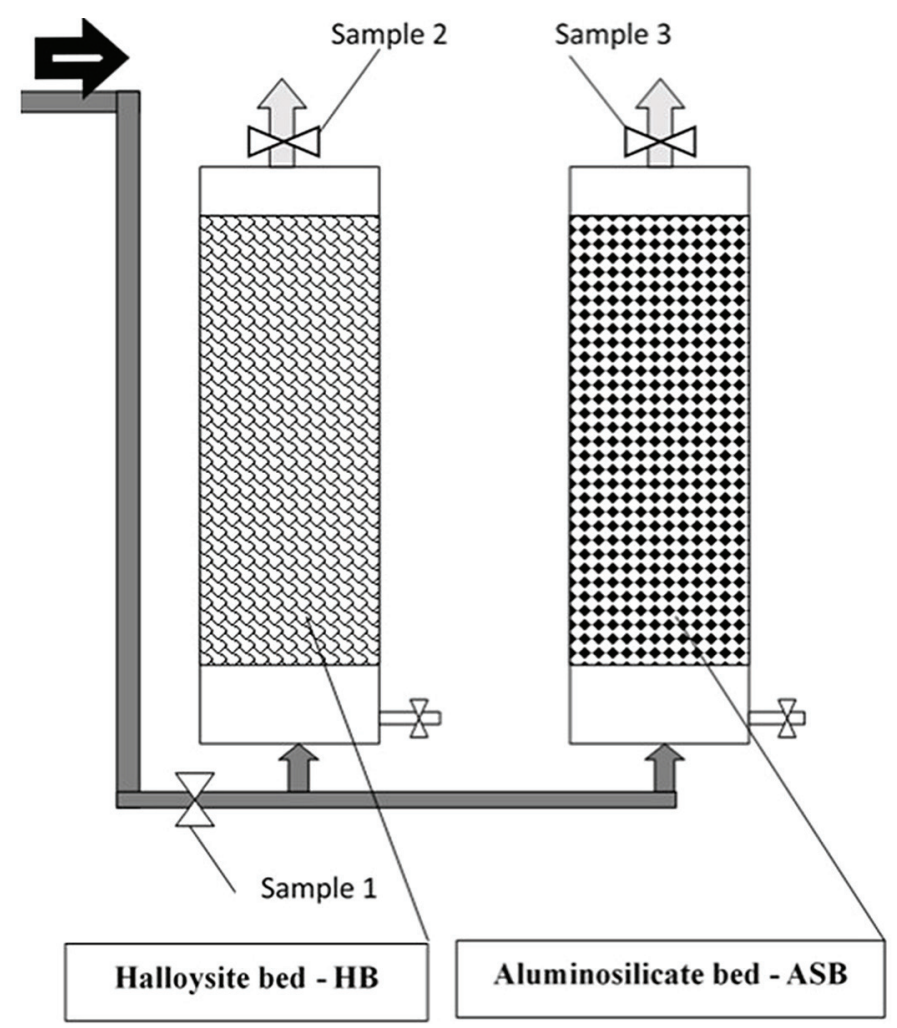

Figure 3. The diagram of the experimental installation for waste gas deodorization from composting processes

enabled to control the flow of the gas during the operation of the beds and sampling. The gas samples were collected to tubes SKC 226-119 and SKC 226-10 every third day and a chromatographic analysis was conducted. The markings of the aldehydes were made on the liquid chromatograph HPLC with the UV detection produced by PerkinElmer Series 200. J\&W H-80 (C-18) column was used, with the dimensions $150 \times 4.6 \mathrm{~mm}$ and the film thickness of $5 \mu \mathrm{m}$. The markings of the organic acids were made on the gas chromatograph GC/FID produced by PerkinElmer AytoSystem XL, using a capillary column DB-Waxo with the dimensions $60 \mathrm{~m} \times 0.53 \mathrm{~mm}$, with the phase thickness of $1 \mu \mathrm{m}$. The exemplary chromatograms obtained are shown in Figures 4 and 5.

The experiment lasted for a month because hard and highly variable industrial conditions caused operation problems and the experiment was suddenly interrupted. The research will be continued after the introduction of design changes in the installation.

\section{RESULTS}

The results of the analyses are presented in the source form (Figures 4-5) and when converted to the conditions of sample collection (Tables 2-6). The samples were taken upstream of the biofilters (Sample 1) as well as downstream of the halloysite $-\mathrm{H}$ biofilter (Sample 2) and aluminosilicate - AS biofilter (Sample 3). The comparison of the results of the concentrations of the individual odour contaminations is shown in Figures 6 and 7.

Figures 4 and 5 present the selected chromatograms on the basis of which the concentrations of organic acids and aldehydes in the examined gas samples taken on the measurement setup in the composting facility were calculated.

The concentrations of acetic acid and acetaldehyde in the examined samples, converted to the amount of the air drawn and the conditions of sample taking are presented in Tables 2-6. The samples were collected each week through the whole experiment. Each weekly sample taking constitutes one series of the study. In each series, three sample of post-process air were collected: one upstream of the biofilters, the second one downstream of the biofilter filled with halloysite, and the third one downstream of the biofilter with the other aluminosilicate. In each study cycle, the concentration of Total Volatile Organic Compounds (TVOC) converted to toluene was provided as well. 

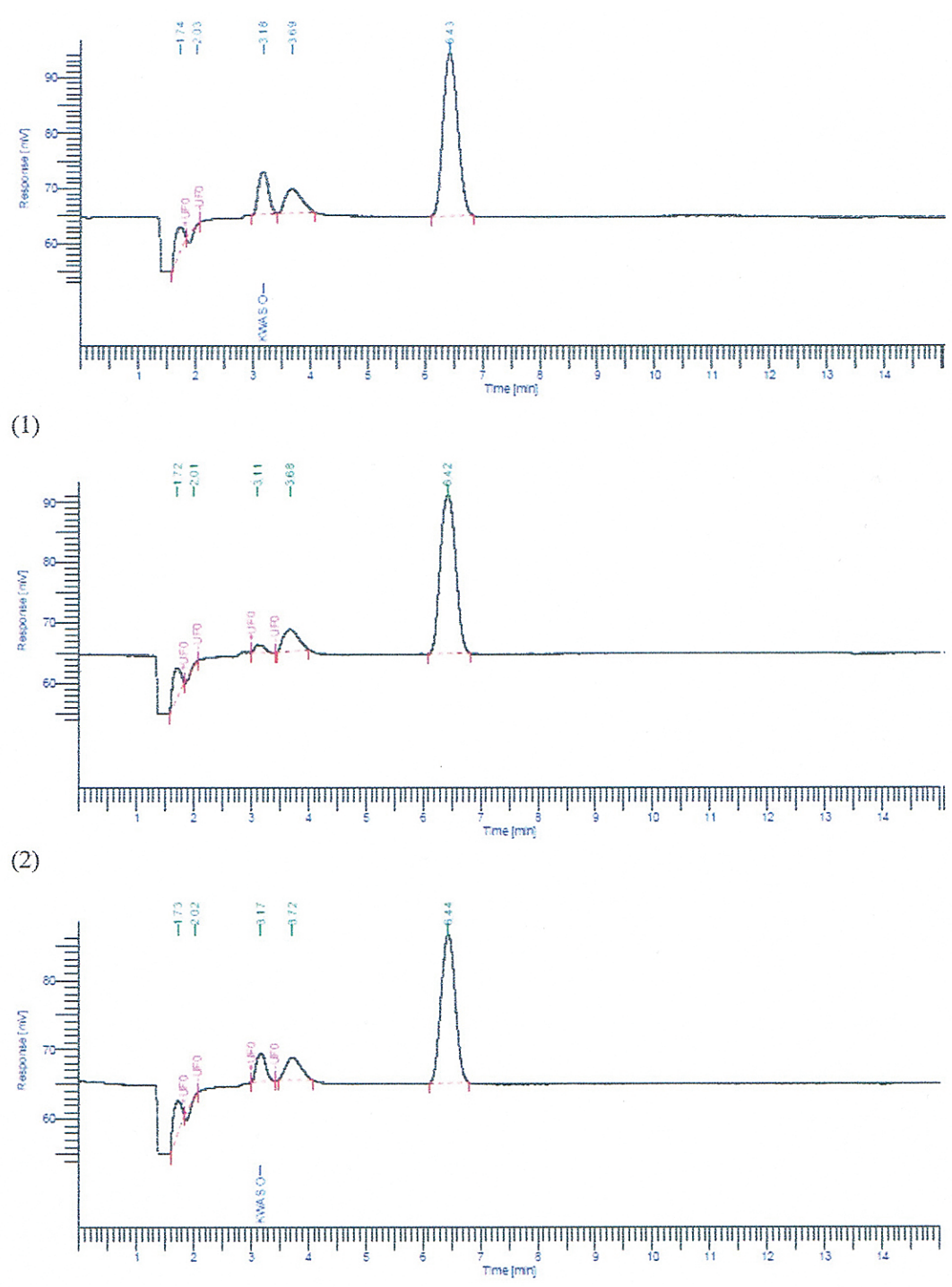

(3)

Figure 4. The comparison of chromatograms showing the decomposition of organic acids in the industrial gas upstream of the biofilters (1) downstream of the H biofilter (2) and the AS biofilter (3)

Tables 2-6 present the concentrations of two basic contaminants present in the examined waste gases emitted from the processing of municipal waste composting, which are significantly malodorous. The concentrations of acetic acid and acetaldehyde are shown with the conditions under which the samples of gases were taken, namely: temperature and humidity. The $\mathrm{pH}$ of gas and leachate were also measured on the test setup. After the first week of experimental operation of the biofilters (Series 1), the concentration of acetic acid in the examined gas after passing through the halloysite bed decreased by $80.36 \%$, whereas after passing through the aluminosilicate bed by $96.87 \%$. The concentrations of acetaldehyde after passing through the mentioned beds were also reduced considerably. In the gas drawn downstream of the biofilter filled with halloysite, the concentration of acetaldehyde was $96.45 \%$ lower than upstream of the biofilters, and $92.19 \%$ lower than downstream of the biofilter with the other aluminosilicate After two weeks of the study (series 2), the concentration of acetic acid was reduced downstream of the halloysite bed by $98.93 \%$ and by $98.71 \%$ downstream of the aluminosilicate bed. The concentration of acetaldehyde also dropped significantly after passing through the biofilter with halloysite by $98.26 \%$ and by $86.05 \%$ in the gas downstream the aluminosilicate bed. Such high percent of the reduction of the concentrations of the analysed odorants resulted from good sorption properties used in biofilters of mineral sorbents. In the initial stage of the experiment the biofilters operated only based on the 


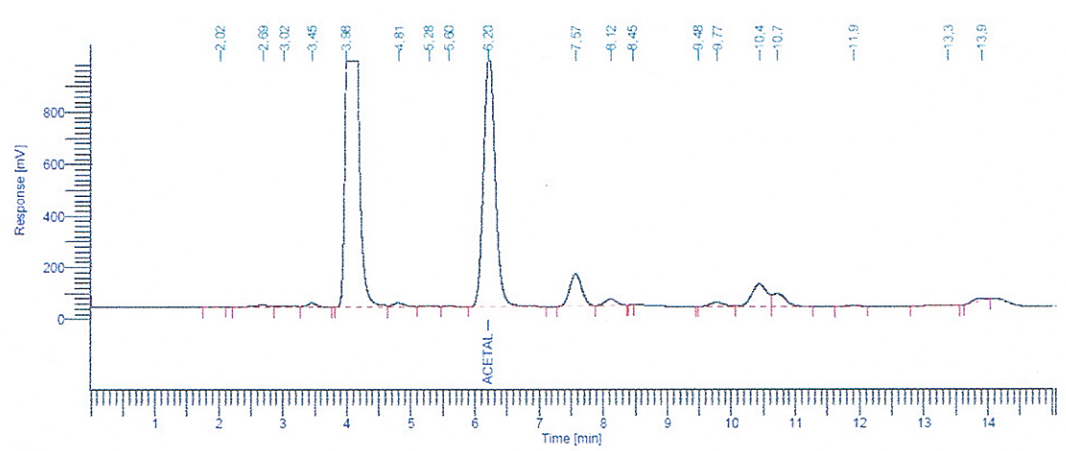

(1)

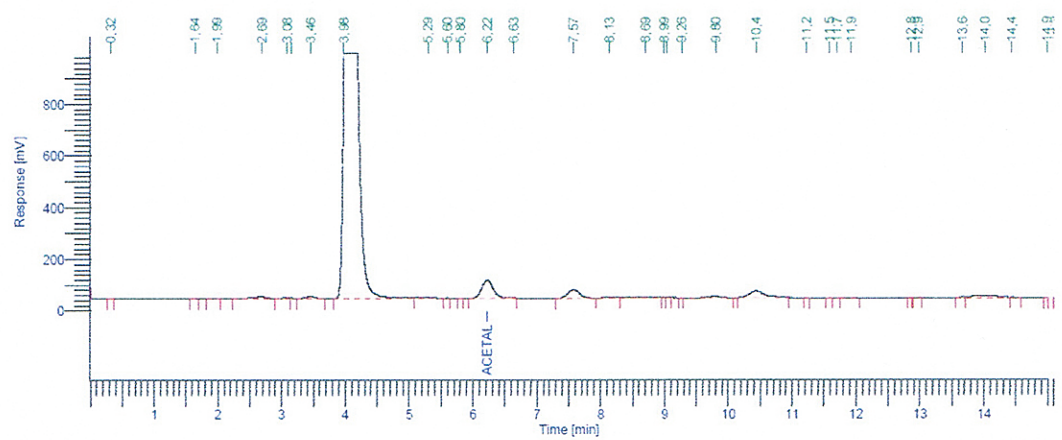

(2)

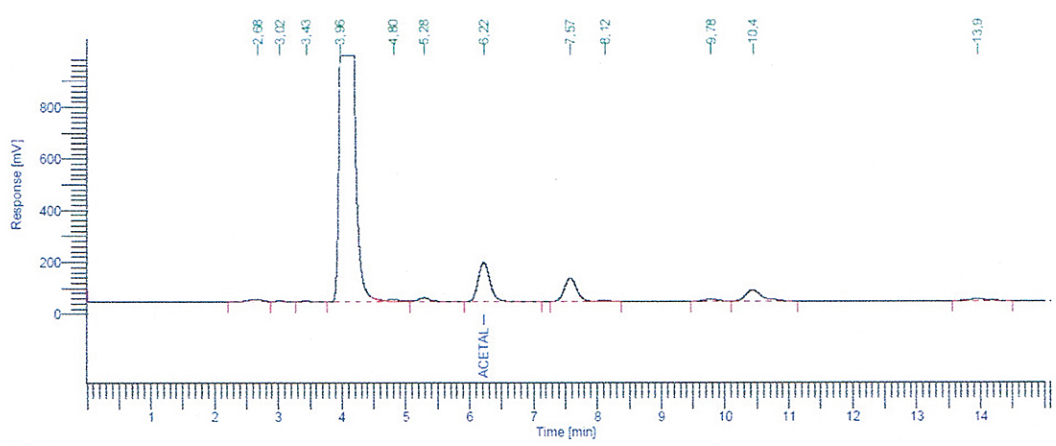

(3)

Figure 5. The comparison of chromatograms showing the decomposition of aldehydes in the industrial gas upstream of the biofilters(1) downstream of the H biofilter (2) and the AS biofilter (3)

Table 2 The analysis results $-1^{\text {st }}$ series

\begin{tabular}{|c|c|c|c|c|}
\hline & Specification & $\begin{array}{c}\text { sample } 1 \\
\text { upstream of biofilters }\end{array}$ & $\begin{array}{c}\text { sample } 2 \\
\text { downstream of } \mathrm{H} \text { biofilter }\end{array}$ & $\begin{array}{c}\text { sample } 3 \\
\text { downstream of AS biofilter }\end{array}$ \\
\hline \multicolumn{2}{|c|}{ Acetic acid $\left[\mathrm{mg} / \mathrm{m}^{3}\right]$} & 4.48 & 0.88 & 0.14 \\
\hline \multicolumn{2}{|c|}{ Acetaldehyde $\left[\mathrm{mg} / \mathrm{m}^{3}\right]$} & 12.68 & 0.45 & 0.99 \\
\hline \multirow{2}{*}{$\mathrm{pH}$} & of gas & 6.40 & 5.55 & 5.92 \\
\hline & of leachate & 6.10 & 6.04 & 6.43 \\
\hline \multicolumn{2}{|c|}{ Temperature $\left[{ }^{\circ} \mathrm{C}\right]$} & - & 23.0 & 29.0 \\
\hline \multicolumn{2}{|c|}{ Humidity [\%] } & - & 71.0 & 97.0 \\
\hline \multicolumn{2}{|c|}{ TVOC converted to toulene $\left[\mathrm{mg} / \mathrm{m}^{3}\right]$} & - & 6.33 & 18.87 \\
\hline
\end{tabular}

sorption of contaminations on the beds. Biofiltration did not take place yet because the microorganisms with which the bed were inoculated need time to multiply and take over the role in the process of post-process gas deodorisation. Therefore, only sorption on the filtration materials took place at that stage. In the first two weeks in the deodorisation process of gases from acetaldehydes, halloysite obtained better results. When analysing Tables 2 and 3 we can also notice that humidity downstream of the biofilter with aluminosilicate was higher than downstream of the biofilter filled 
with halloysite. It may prove better sorption properties of halloysite which to a greater extent dried very humid gas directed onto both filters.

In the next weeks (series 3 and 4) acetaldehyde was much better absorbed on the halloysite bed. It was proven by greater reduction of concentrations in the halloysite biofilter (reduction by $93.81 \%$ and by $93.35 \%$ ) than in the case of the biofilter with aluminosilicate (reduction by $70.66 \%$ ). In the third week (series 3 ) the halloysite bed reduced the concentrations of acetic acid much less than the aluminosilicate bed. After passing the gas though the biofilter with halloysite, the concentration of acetic acid dropped by $50.80 \%$, and after passing through the biofilter with aluminosilicate - by $76.66 \%$.

Table 3 The analysis results $-2^{\text {nd }}$ series

\begin{tabular}{|c|c|c|c|c|}
\hline & Specification & $\begin{array}{c}\text { sample } 1 \\
\text { upstream of biofilters }\end{array}$ & $\begin{array}{c}\text { sample } 2 \\
\text { downstream of } \mathrm{H} \text { biofilter }\end{array}$ & $\begin{array}{c}\text { sample } 3 \\
\text { downstream of AS biofilter }\end{array}$ \\
\hline \multicolumn{2}{|c|}{ Acetic acid $\left[\mathrm{mg} / \mathrm{m}^{3}\right]$} & 17.82 & 0.19 & 0.23 \\
\hline \multicolumn{2}{|c|}{ Acetaldehyde $\left[\mathrm{mg} / \mathrm{m}^{3}\right]$} & 34.48 & 0.6 & 4.81 \\
\hline \multirow{2}{*}{$\mathrm{pH}$} & of gas & 6.08 & 5.67 & 5.90 \\
\hline & of leachate & 6.26 & 7.08 & 7.36 \\
\hline \multicolumn{2}{|c|}{ Temperature $\left[{ }^{\circ} \mathrm{C}\right]$} & - & 17.0 & 23.5 \\
\hline \multicolumn{2}{|c|}{ Humidity [\%] } & - & 74.0 & 96.3 \\
\hline \multicolumn{2}{|c|}{ TVOC converted to toulene $\left[\mathrm{mg} / \mathrm{m}^{3}\right]$} & - & 18.72 & 42.24 \\
\hline
\end{tabular}

Table 4 The analysis results $-3^{\text {rd }}$ series

\begin{tabular}{|c|c|c|c|c|}
\hline & Specification & $\begin{array}{c}\text { sample } 1 \\
\text { upstream of biofilters }\end{array}$ & $\begin{array}{c}\text { sample } 2 \\
\text { downstream of } \mathrm{H} \text { biofilter }\end{array}$ & $\begin{array}{c}\text { sample } 3 \\
\text { downstream of AS biofilter }\end{array}$ \\
\hline \multicolumn{2}{|c|}{ Acetic acid $\left[\mathrm{mg} / \mathrm{m}^{3}\right]$} & 4.37 & 2.15 & 1.02 \\
\hline \multicolumn{2}{|c|}{ Acetaldehyde $\left[\mathrm{mg} / \mathrm{m}^{3}\right]$} & 0.97 & 0.06 & 1.29 \\
\hline \multirow{2}{*}{$\mathrm{pH}$} & of gas & 5.35 & 6.22 & 6.04 \\
\hline & of leachate & 6.03 & 6.34 & 6.21 \\
\hline \multicolumn{2}{|c|}{ Temperature $\left[{ }^{\circ} \mathrm{C}\right]$} & - & 23.4 & 23.8 \\
\hline \multicolumn{2}{|c|}{ Humidity [\%] } & - & 87.0 & 90.9 \\
\hline \multicolumn{2}{|c|}{ TVOC converted to toulene $\left[\mathrm{mg} / \mathrm{m}^{3}\right]$} & - & 23.0 & 22.42 \\
\hline
\end{tabular}

Table 5 The analysis results $-4^{\text {th }}$ series

\begin{tabular}{|c|c|c|c|c|}
\hline & Specification & $\begin{array}{c}\text { sample } 1 \\
\text { upstream of biofilters }\end{array}$ & $\begin{array}{c}\text { sample } 2 \\
\text { downstream of } \mathrm{H} \text { biofilter }\end{array}$ & $\begin{array}{c}\text { sample } 3 \\
\text { downstream of AS biofilter }\end{array}$ \\
\hline \multicolumn{2}{|c|}{ Acetic acid $\left[\mathrm{mg} / \mathrm{m}^{3}\right]$} & - & - & - \\
\hline \multicolumn{2}{|c|}{ Acetaldehyde $\left[\mathrm{mg} / \mathrm{m}^{3}\right]$} & 6.92 & 0.46 & 2.03 \\
\hline \multirow{2}{*}{$\mathrm{pH}$} & of gas & 5.47 & 5.92 & 5.64 \\
\hline & of leachate & 6.42 & 6.98 & 6.67 \\
\hline \multicolumn{2}{|c|}{ Temperature $\left[{ }^{\circ} \mathrm{C}\right]$} & - & 17.5 & 23.0 \\
\hline \multicolumn{2}{|c|}{ Humidity [\%] } & - & 66.0 & 72.1 \\
\hline \multicolumn{2}{|c|}{ TVOC converted to toulene $\left[\mathrm{mg} / \mathrm{m}^{3}\right]$} & - & 22.48 & 25.24 \\
\hline
\end{tabular}

Table 6 The analysis results $-5^{\text {th }}$ series

\begin{tabular}{|c|c|c|c|c|}
\hline & Specification & $\begin{array}{c}\text { sample1 } \\
\text { upstream of biofilters }\end{array}$ & $\begin{array}{c}\text { sample } 2 \\
\text { downstream of } \mathrm{H} \text { biofilter }\end{array}$ & $\begin{array}{c}\text { sample } 3 \\
\text { downstream of AS biofilter }\end{array}$ \\
\hline \multicolumn{2}{|c|}{ Acetic acid $\left[\mathrm{mg} / \mathrm{m}^{3}\right]$} & 128.10 & 146.65 & 135.73 \\
\hline \multicolumn{2}{|c|}{ Acetaldehyde $\left[\mathrm{mg} / \mathrm{m}^{3}\right]$} & 10.65 & 0.19 & 0.67 \\
\hline \multirow{2}{*}{$\mathrm{pH}$} & of gas & 5.67 & 5.40 & 5.51 \\
\hline & of leachate & 5.70 & 5.49 & 5.64 \\
\hline \multicolumn{2}{|c|}{ Temperature $\left[{ }^{\circ} \mathrm{C}\right]$} & - & 28.3 & 25.0 \\
\hline \multicolumn{2}{|c|}{ Humidity [\%] } & - & 97.0 & 97.1 \\
\hline
\end{tabular}


Humidity of the gas downstream of the biofilters, throughout the whole experiment, was higher in the case of the other aluminosilicate. The research findings show that out of the two examined mineral sorbents, halloysite has better sorption properties (Figure 6 and 7). It is also proven by the changes in the TVOC concentrations (Tables 2-5).

In the fifth week of the operation of experimental biofilters, the conditions drastically worsened. The beds were flooded from the bottom with leachate with silt which in addition started to emit odours. It could be caused by the bacterial flora developing spontaneously during the operation of the biofilters other than the one inoculated (entered in the biofilters). The experiment had to be interrupted and design changes in the installation had to be introduced. At that stage, the concentrations of acetic acid downstream of the biofilters increased in comparison with gas on the inlet. In the case of halloysite, they went up by $14.48 \%$, and in the case of the other aluminosilicate - by $5.96 \%$. The anaerobic and putrefactive processes which started to prevail and emit odours were probably the reason. It was surprising that the reduction of the concentrations of acetaldehyde was still going on, even by $90 \%$ in both cases (Figures 6 and 7). Attention should also be paid to the variable concentrations of acetic acid and acetaldehyde before the deodorisation process in the biofilters.

At the moment of interrupting the research, the microorganisms inoculated to the beds had not started the gas deodorisation process yet. It means that mainly the sorption of the analysed odorants took place throughout the whole experiment. In spite of the fact that the conditions of conducting the experiment were far from optimum and highly variable, halloysite turned out to be better out of the two examined mineral sorbents.

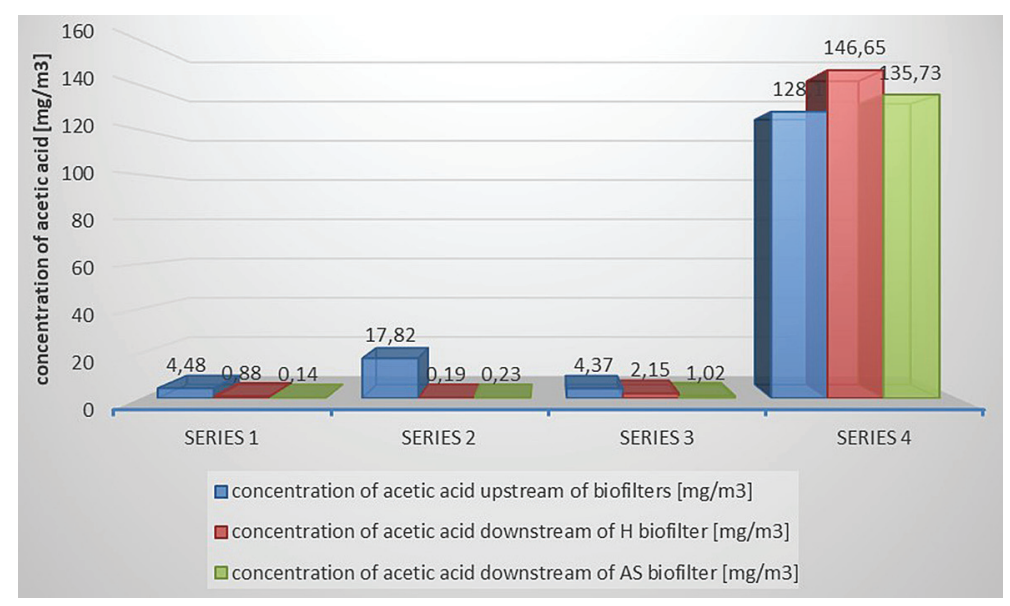

Figure 6 Changes in the concentrations of acetic acid in the gas emitted from the composting facility after passing it through the halloysite bed $(\mathrm{H})$ and aluminosilicate bed (AS)

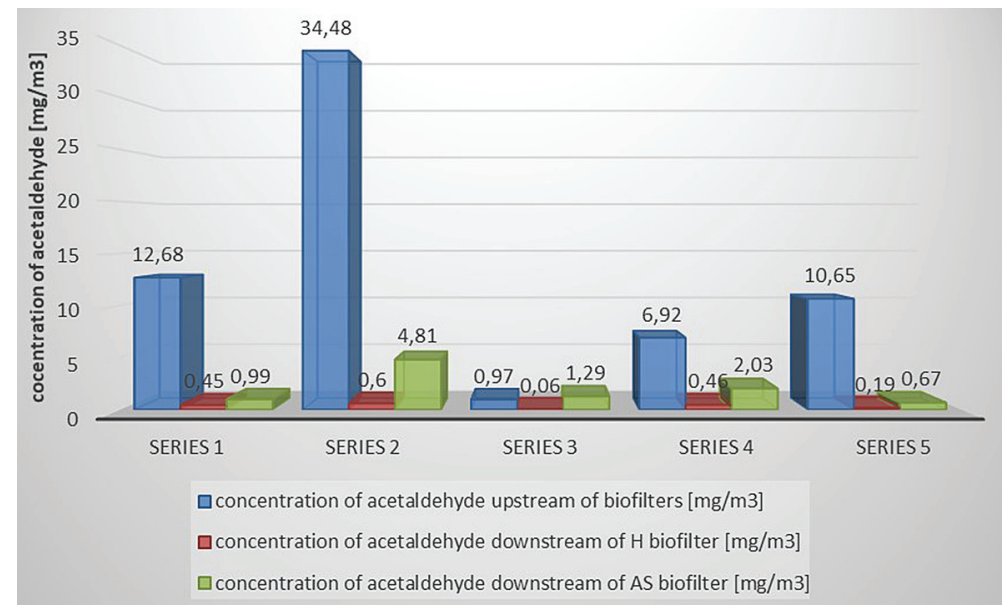

Figure 7 Changes in the concentrations of acetaldehyde in the gas emitted from the composting facility after passing it through the halloysite bed $(\mathrm{H})$ and aluminosilicate bed (AS) 


\section{CONCLUSIONS}

1. In the first weeks of the study, before the sorbents soaked, halloysite reduced the concentrations of acetic acid in 80-99\%, and acetaldehyde - in 96-98\%. The other aluminosilicate caused analogously the drop in those concentration by $97-98 \%$ and $92-86 \%$.

2. In the experiment planned in the semi-technical scale, it was not possible to determine the general performances of mineral biofilters due to the unstable operating conditions and the ending of the experiment ahead of time.

3. The halloysite sorbent turned out to be a potentially more efficient than the other aluminosilicate sorbent.

\section{REFERENCES}

1. Banaś D., Kubala-Kukuś A., Braziewicz J., Majewska U., Pajek M., Wudarczyk-Moćko J., Czech K., Garnuszek M., Słomkiewicz P., Szczepanik B. 2013. Study of properties of chemically modified samples of halloysite mineral with X-ray fluorescence and $\mathrm{X}$-ray powder diffraction methods. Radiation Physics and Chemistry, 93, 129-134.

2. Du M., Guo B., Jia D. 2010. Newly emerging applications of halloysite nanotubes: a review. Polymer International, 59, 574-582.

3. Guggenheim S.S., Adams J.M., Bain D.C., Bergaya F., Brigatti M.F., Drits V.A., Formoso M.L.L., Galán E., Kogure T., Stanjek H. 2006. Summary of recommendations of nomenclature committees relevant to clay mineralogy: report of the Association Internationale pour l'Etude des Argiles (AIPEA) Nomenclature Committee for 2006. Clays and Clay Minerals, 54(6), 761-772.

4. Jędrczak A., Haziak K. 2005. Defining requirements for composting and other methods of biological processing of waste. Pracownie Badawczo-Projektowe EKOSYSTEM, Zielona Góra. (in Polish)

5. Kośmider J., Mazur-Chrzanowska B., Wyszyński B. 2002. Odours. Wyd. Nauk. PWN, Warszawa. (in Polish)

6. Kwarciak-Kozłowska A., Bańka B. 2014. Biofiltration as a Method of the Neutralization of Waste Forming during Composting Biodegradable Fraction of Municipal and Industrial Waste. Inżynieria i Ochrona Środowiska, 17(4), 631-645. (in Polish)

7. Kwaśny J., Balcerzak W. 2014. Characteristics of selected indirect methods of reducing the emission of odors. Archives of Waste Management and Environmental Protection, 16(4), 125-134.
8. Machnicka A., Nowicka E. 2016. The application of halloysite to reduce the concentration of contaminants in municipal wastewater. Inżynieria Ekologiczna, 50, 217-222. (in Polish)

9. Matusik J., Scholtzova E., Tunega D. 2012. Influence of synthesis conditions on the formation of a kaolinite-methanol complex and simulation of its vibrational spectra. Clays Clay Miner, 60, 227-239.

10. Mingliang D.M., Guo B., Jia D. 2010. Newly emerging applications of halloysite nanotubes: a Review. Polymer International, 59(5), 574-582.

11. Pasbakhsh P., How H.K., Piao Ch. S. 2012. Modification of halloysite nanotubes with glycidyl methacrylate. Conference materials 1, 22 ${ }^{\text {nd }}$ Australian Clay Minerals Society Conference - Mildura, 1-4.

12. Radziemska M. 2018. Study of applying naturally occurring mineral sorbents of Poland (dolomite, halloysite, chalcedonite) for aided phytostabilization of soil polluted with heavy metals. Catena, 163, 123-129.

13. Ravindra K., Manasi G., Sheetal G., Kumar P.B. 2012. Halloysite Nanotubes and Applications: A Review. Journal of Advanced Scientific Research, 3(2), 25-29.

14. Sakiewicz P., Cebula J., Piotrowski K., Nowosielski R., Wilk R., Nowicki M. 2005. Application of micro- and nanostructural multifunctional halloysitebased sorbents from DUNINO deposit in selected biotechnological processes. Journal of Achievements in Materials and Manufacturing Engineering, 69, 69-78.

15. Sówka I., Miller U., Sobczyński P. 2014. Emission of odours from the processes of composting municipal waste. Przemysł Chemiczny, 1, 93(15), 1000-1003. (in Polish)

16. Szczygielska A., Kijeński J. 2010. The application of halloysite as a filler for the modification of polypropylene. Part 1. The Characteristics of Halloysite as a Filler. Kompozyty, 10(2), 181-185. (in Polish)

17. Veerabadran N.G., Price R.R., Lvov Y.M. 2007. Nano: Brief Reports and Reviews, 2(2), 115-120.

18. Wieczorek A. 1998. The influence of the emission of volatile organic compounds on the smell of waste gases from waste composting facility. Ochrona Środowiska, 1(68), 33-35. (in Polish)

19. Yuan P., Southon P.D., Liu Z., Green M.E.R., Hook J.M., Antill S.J., Kepert C.J. 2008. Functionalization of halloysite clay nanotubes by grafting with $\gamma$-aminopropyltriethoxysilane. The Journal of PhysicalChemistry C, 112, 15742-15751.

20. Żarczyński A., Rosiak K., Anielak P., WolfW. 2014. Practical methods of clearing biogas from hydrogen sulphide. Part 1. Application of solid sorbents, Acta Innovations, 12, 24-34. 